\title{
A regressing spindle cell tumour of Reed
}

\author{
Simon Tso, ${ }^{1}$ William Hunt, ${ }^{1}$ Joanna E Gach ${ }^{1,2}$
}

Department of Dermatology, University Hospitals Coventry and Warwickshire NHS Trust, Coventry, UK

${ }^{2}$ Department of Dermatology, Birmingham Women's and Children's NHS Foundation Trust, Birmingham, UK

\section{Correspondence to}

Dr Simon Tso,

simontso@doctors.org.uk

Accepted 1 November 2017

\section{DESCRIPTION}

Spindle cell tumour of Reed is a benign melanocytic naevus which usually presents as a deeply pigmented mole. It is more commonly found on the lower extremities of young girls. It is an uncommon naevus but its incidence and prevalence are not known. A Reed naevus typically goes through a rapid initial growth phrase before stabilising in size and then regresses over time. ${ }^{1}$ Awareness of Reed naevus has been demonstrated to be low, even among dermatology doctors. ${ }^{2}$

The main dermoscopic patterns (when observed under magnification using a dermatoscope) observed are the starburst pattern $(50.6 \%$ of cases), pattern of dotted vessels (19.3\%), globular pattern (17\%) and atypical pattern $(9.0 \%) .^{3}$

Figure 1A illustrates a $7 \mathrm{mmx} 5 \mathrm{~mm}$ symmetrical deeply pigmented plaque on the right knee of a 5-year-old girl. Figure $1 \mathrm{~B}$ shows the dermatoscopic symmetrical starburst pattern with regular pigment network. The size and the extent of pigmentation of the Reed naevus regressed over a 2 -year observation period and almost disappeared as shown in the photograph (figure 2A,B).

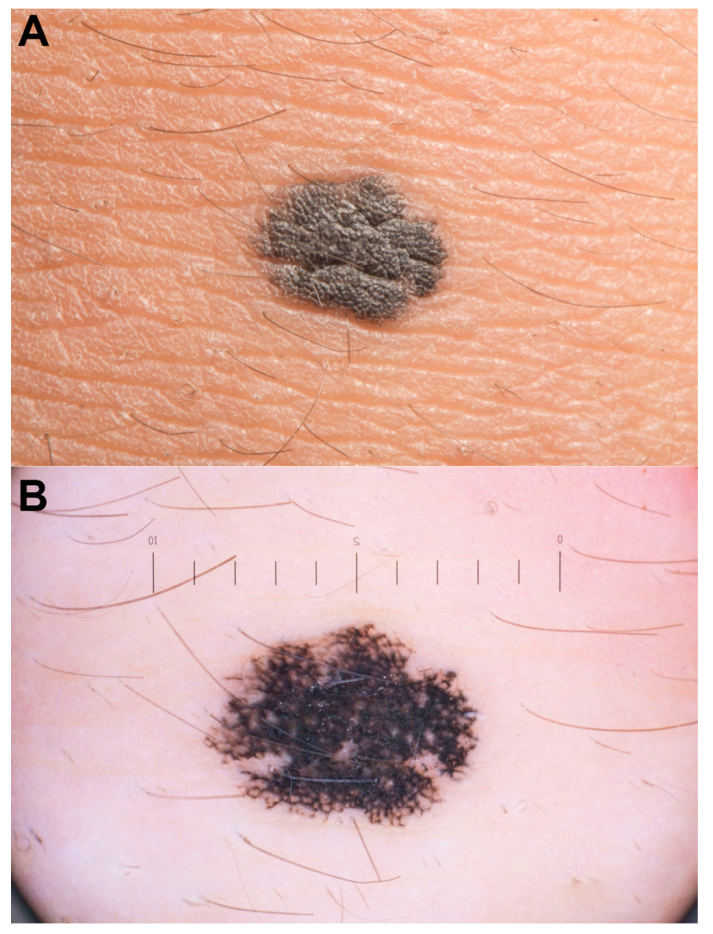

To cite: Tso S, Hunt W Gach JE. BMJ Case Rep Published Online First: [please include Day Month Year]. doi:10.1136/bcr-2017222002
Figure 1 (A) A $7 \mathrm{~mm} \times 5 \mathrm{~mm}$ deeply pigmented spindle pigmented plaque with a starburst pattern. cell tumour of Reed on the right knee. (B) A deeply

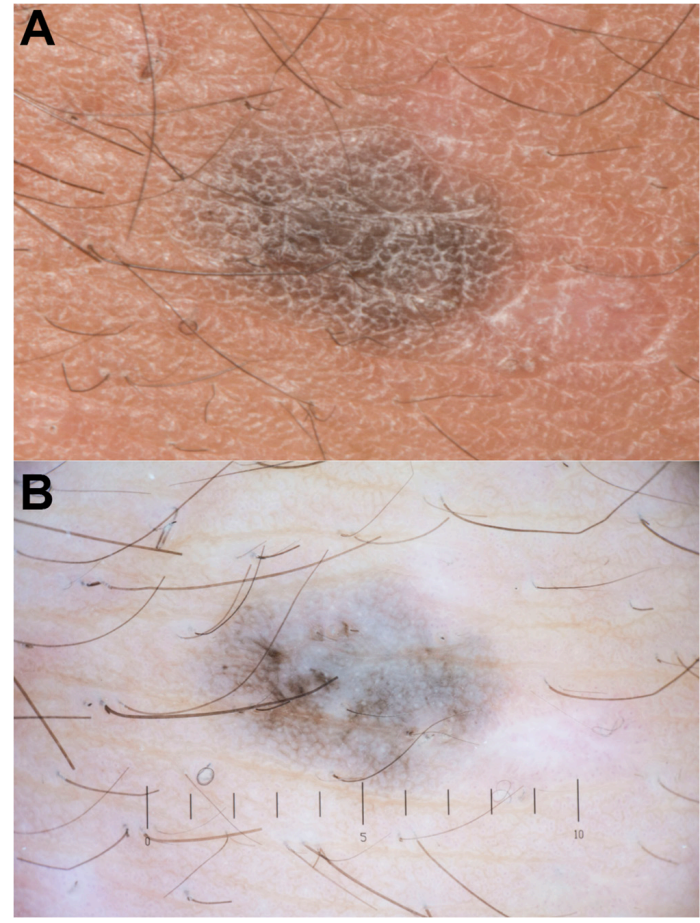

Figure 2 (A) A regressing Reed naevus. (B) A pale plaque. Without observing the natural evolution of the Reed naevus, the white and blue veil sign in (B) alone could be misinterpreted as melanoma.

International guidelines recommend that a flat Reed naevus with symmetrical morphology may be observed until its growth is stabilised or the naevus completely disappeared. ${ }^{3}$ However, an excision biopsy should be considered if a skin lesion resembling a Reed naevus occurs in adulthood or if there is any concern about the lesion, such as having asymmetrical morphology

\section{Patient's perspective}

Our initial thoughts were to have the skin lump removed from a parent's perspective as it was causing my daughter unnecessary stress and my concern was, she became conscious of it, that was unbalancing her in a negative emotional way. On our first visit we had a specialist team look and examine her which was fantastically reassuring as a parent. Because of the attention and care we received, we chose to withhold any excision and review and monitor it. Over the course of the last 12 months, we saw a real submission of the skin lump and were very relieved we did not take the option at surgery. 


\section{Learning points}

- The diagnosis of a Reed naevus should only be made by dermatologists experienced in skin oncology, and we recommend that primary care physicians and non-dermatologists should always refer suspicious or evolving moles to dermatologists for assessment.

- Clinical diagnosis and expectant management has its place for the management of a benign Reed naevus in limited circumstances (ie, morphologically symmetrical and macular lesions in small children) and our management is in line with international consensus guidelines and parental preference of monitoring the lesion.

- The editorial reviewer of our case report recommended that for purposes of published cases a skin biopsy is very important to support the diagnosis and rule out atypia, features of uncertain malignant potential or melanoma. In absence of skin biopsy, the reviewer suggests a much longer clinical follow-up to ensure the stability of the lesion and health of the child. or growth, or is nodular in nature, in order to rule out atypical Spitzoid tumour or Spitzoid melanoma. ${ }^{3}$

Acknowledgements We would like to thank the reviewer for the constructive feedback on our submission.

Contributors All authors were involved in the care of the patient. ST prepared the initial draft of the manuscript. WH and JG revised the draft and contributed to its important intellectual content. All authors provided final approval of the version published and agreed to be accountable for all aspects of the work.

Competing interests None declared.

Patient consent Guardian consent obtained.

Provenance and peer review Not commissioned; externally peer reviewed.

(C) BMJ Publishing Group Ltd (unless otherwise stated in the text of the article) 2017. All rights reserved. No commercial use is permitted unless otherwise expressly granted.

\section{REFERENCES}

1 Yoradjian A, Enokihara MM, Paschoal FM. Spitz nevus and Reed nevus. An Bras Dermatol 2012;87:349-59.

2 Webber SA, Siller G, Soyer HP. Pigmented spindle cell naevus of Reed: a controversial diagnostic entity in Australia. Australas J Dermatol 2011;52:104-8.

3 Lallas A, Apalla Z, loannides D, et al. Update on dermoscopy of Spitz/Reed naevi and management guidelines by the International Dermoscopy Society. $\mathrm{Br} J$ Dermatol 2017; 177:645-55.

Copyright 2017 BMJ Publishing Group. All rights reserved. For permission to reuse any of this content visit http://group.bmj.com/group/rights-licensing/permissions.

BMJ Case Report Fellows may re-use this article for personal use and teaching without any further permission.

Become a Fellow of BMJ Case Reports today and you can:

- Submit as many cases as you like

- Enjoy fast sympathetic peer review and rapid publication of accepted articles

- Access all the published articles

- Re-use any of the published material for personal use and teaching without further permission

For information on Institutional Fellowships contact consortiasales@bmjgroup.com

Visit casereports.bmj.com for more articles like this and to become a Fellow 